\title{
THE EVALUATION OF ALGORITHMS FOR DETERMINATION OF THE RELIABILITY INDEX
}

\begin{abstract}
A. DUDZIK ${ }^{1}$, U. RADOŃ ${ }^{2}$
The study deals with stability and dynamic problems in bar structures using a probabilistic approach. Structural design parameters are defined as deterministic values and also as random variables, which are not correlated. The criterion of structural failure is expressed by the condition of non-exceeding the admissible load multiplier and condition of non-exceeding the admissible vertical displacement. The Hasofer-Lind index was used as a reliability measure. The primary research tool is the FORM method. In order to verify the correctness of the calculations Monte Carlo and Importance Sampling methods were used. The sensitivity of the reliability index to the random variables was defined. The limit state function is not an explicit function of random variables. This dependence was determined using a numerical procedure, e.g. the finite element methods. The paper aims to present the communication between the STAND reliability analysis program and the KRATA and MES3D external FE programs.
\end{abstract}

Keywords: random variables, reliability index, FORM method, sensitivity of the reliability index, stability, dynamic analysis, equilibrium path, design point.

\section{INTRODUCTION}

The probabilistic finite element methods for analysis of structures have become of increasing interest in recent years. In early applications of reliability analysis methods, it was accepted that the limit state function is an explicit function of random variables. Such functional dependency can be

\footnotetext{
${ }^{1}$ MSc., Kielce University of Technology, Faculty of Civil Engineering and Architecture, Al. 1000-lecia PP 7, 25-314 Kielce, Poland, e-mail: agad@tu.kielce.pl

${ }^{2}$ DSc., Kielce University of Technology, Faculty of Civil Engineering and Architecture, Al. 1000-lecia PP 7, 25-314

Kielce, Poland, e-mail: zmbur@tu.kielce.pl
} 
realized only for very simple examples. In practical realizations, this dependence is not explicit and it is determined using numerical procedure, e.g. the finite element methods.

This article aims to present the communication between the STAND reliability analysis program and the KRATA [7] was developed by the present author and MES3D [11] was made by Szaniec (Fig. 1). The STAND program was developed at the Institute of Fundamental Technological Research of the Polish Academy of Sciences by Knabel, Kolanek, Nguyen Hoang, Stocki and Tauzowski, Lasota [4], [10].

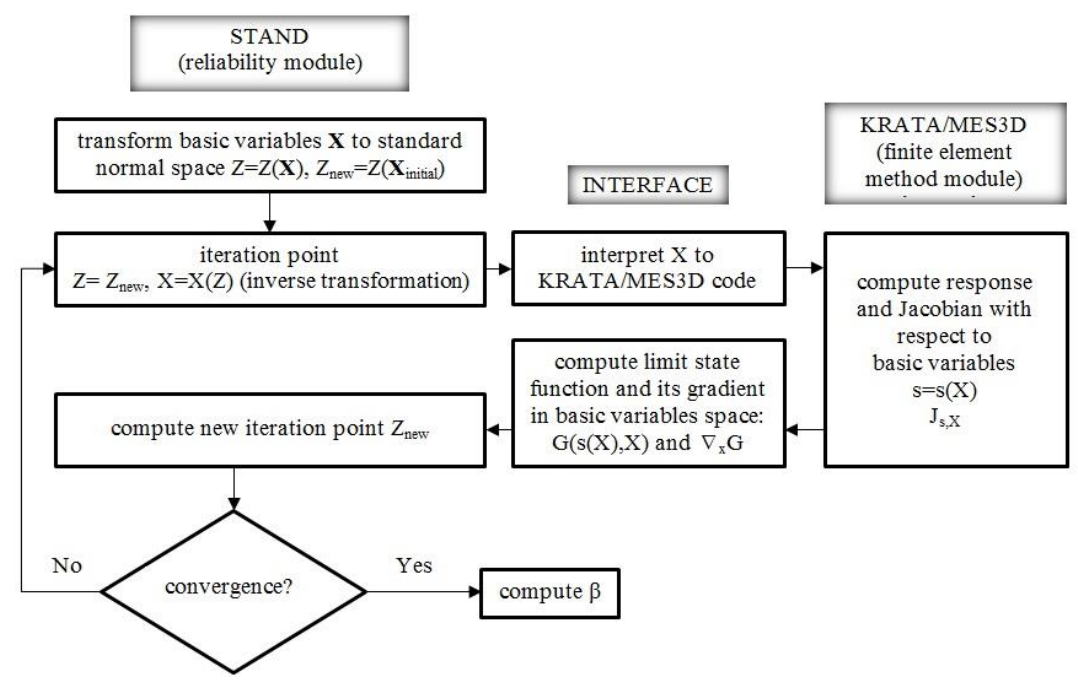

Fig. 1. Scheme of communication between STAND software and external FE programs.

The first step of the reliability analysis task using STAND is a definition of the stochastic model. The user must provide marginal distributions of the basic random variables, for correlated variables, their correlation matrix (in STAND, an approximation joint probability density function is built by means of the so-called Nataf model [5]). At this step, definitions of the so-called external variables, which are outputs of finite element method programs, can also be introduced. Basic random variables are not correlated. After defining the variables, the limit state function is defined. In the paper, the condition of non-exceeding admissible load multiplier and condition of non-exceeding the admissible vertical displacement are considered as the limit state functions.

The consecutive steps are dedicated to the selection, parameter setting and execution of the reliability analysis algorithm. The most computationally efficient methods for failure probability estimation are based on an approximation of the failure domain in the standard normal space. In 
FORM the failure domain is approximated by the half space that is defined using the limit state surface linearized in the so-called design point. In the standard normal space, the design point is the point on the limit state surface which is closest to the origin. Finding a design point is a task for non-linear programming with limitations. There are two standard, gradient based algorithms for solving this problem implemented in STAND. These are the Abdo-Rackwitz-Fiessler [1] algorithm, and the improved Hasofer-Lind-Rackwitz-Fiessler [6] algorithm.

\section{Probabilistic Methods IN THE STABILITY ANALYSIS OF LAMELLA DOME}

The first part of present study considers the problems of stability and reliability of truss structures subjected to considerable displacements and susceptible to stability loss from the condition of node snapping. Stability analysis of structure is done by means of the finite element method.

The FORM method was applied to the reliability analysis for the node snapping in the Lamella dome (Fig. 2). The structure was designed of tubular sections RO180x8. The elements were made of $\mathrm{S} 355 \mathrm{NH}$ steel with the yield point $\mathrm{f}_{\mathrm{y}}=355 \mathrm{MPa}$ and the modulus of elasticity $\mathrm{E}=210 \mathrm{GPa}$. Conditions support defined as: a simply supported at nodes 32-61 and columns in nodes 2, 4, 6, 8, 10, 12, 16, 20, 24, 28 (Fig. 2).
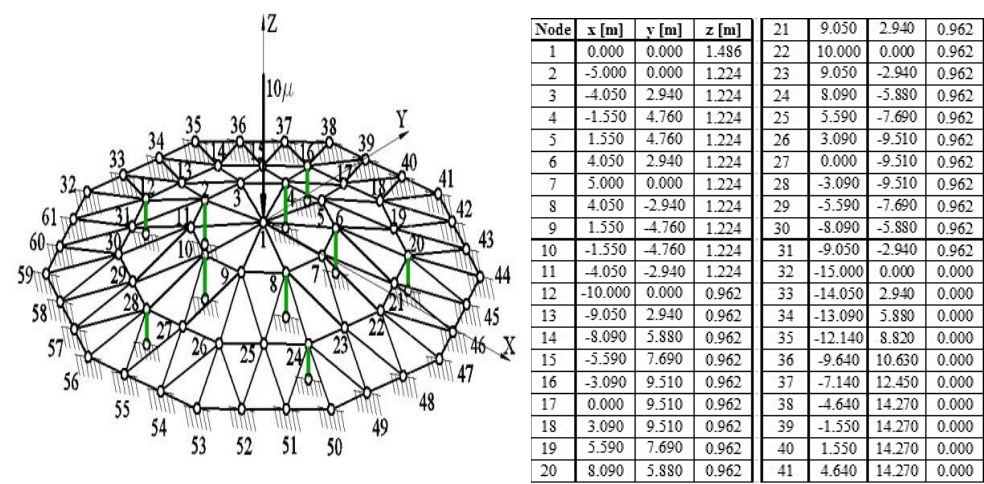

\begin{tabular}{|l|c|c|c|}
\hline 42 & 7.140 & 12.450 & 0.000 \\
\hline 43 & 9.640 & 10.630 & 0.000 \\
\hline 44 & 12.140 & 8.820 & 0.000 \\
\hline 45 & 13.090 & 5.880 & 0.000 \\
\hline 46 & 14.050 & 2.940 & 0.000 \\
\hline 47 & 15.000 & 0.000 & 0.000 \\
\hline 48 & 14.050 & -2.940 & 0.000 \\
\hline 49 & 13.090 & -5.850 & 0.000 \\
\hline 50 & 12.140 & -8.820 & 0.000 \\
\hline 51 & 9.640 & -10.630 & 0.000 \\
\hline 52 & 7.140 & -12.450 & 0.000 \\
\hline 53 & 4.640 & -14.270 & 0.000 \\
\hline 54 & 1.550 & -14.270 & 0.000 \\
\hline 55 & -1.550 & -14.270 & 0.000 \\
\hline 56 & -4.640 & -14.270 & 0.000 \\
\hline 57 & -7.140 & -12.450 & 0.000 \\
\hline 58 & -9.640 & -10.630 & 0.000 \\
\hline 59 & -12.140 & -8.820 & 0.000 \\
\hline 60 & -13.090 & -5.850 & 0.000 \\
\hline 61 & -14.050 & -2.940 & 0.000 \\
\hline
\end{tabular}

Fig. 2. The mesh elements and geometry of truss structure.

The assumption that the moment of the node snapping will never be preceded by the buckling of individual bars of the structure was also validated. Identification of the proper way of stability loss is the starting point for the selection of appropriate limit state function in reliability analysis. In 
connection with the above, the load bearing condition due to buckling behaviour for the most straining rod at the time of the node snapping (bar between nodes 1 and 7) was checked.

Computational data: steel grade S355NH, yield strength $\mathrm{f}_{\mathrm{y}}=355 \mathrm{~N} / \mathrm{mm}^{2}$ for $\mathrm{t} \leq 40 \mathrm{~mm}$, elasticity modulus $\mathrm{E}=210000 \mathrm{~N} / \mathrm{mm}^{2}$, coefficients: $\gamma_{\mathrm{M} 0}=1, \gamma_{\mathrm{M} 1}=1$, the cross-section RO 180x 8 was taken for which: external diameter $\mathrm{d}=180 \mathrm{~mm}$, wall thickness $\mathrm{t}=8 \mathrm{~mm}$, cross sectional area $\mathrm{A}=43.21 \mathrm{~cm}^{2}$, moment of inertia $\mathrm{J}=1601.23 \mathrm{~cm}^{4}$, buckling length of the $\operatorname{rod} \mathrm{L}_{\mathrm{CR}}=5098 \mathrm{~mm}$, computational axial force in the bar at the time of node snapping $\mathrm{N}_{\mathrm{Ed}}=767 \mathrm{kN}$.

Class of section in compression was checked:

$$
\varepsilon=\sqrt{\frac{235}{f_{y}}}=\sqrt{\frac{235}{355}}=0.81, \frac{\mathrm{d}}{\mathrm{t}}=\frac{180}{8}=22.5<50 \varepsilon^{2}=32.81 \text { Section with Class } 1
$$

Buckling carrying capacity was estimated $N_{C R}=1275.65 \mathrm{kN}$. The relative slenderness ratio for elastic flexural buckling was determined: $\bar{\lambda}=1.097$. For the circular profiles of S355NH steel, for curve "a" (Table 6.2 in accordance with [3]), the imperfection parameter $\alpha=0.21$ (Table 6.1 in accordance with [3]) is found and then the value of flexural buckling is calculated: $\Phi=1.195$ and the buckling ratio: $\chi=0.598$. On the basis of these data, the value of the load due to the buckling was estimated: $N_{b, R d}=917.8 \mathrm{kN}$. Buckling carrying capacity condition was checked:

$\frac{\mathrm{N}_{\mathrm{Ed}}}{\mathrm{N}_{\mathrm{b}, \mathrm{Rd}}}=\frac{767 \mathrm{kN}}{917.8 \mathrm{kN}}=0.84<1$. The buckling carrying capacity condition due to buckling is met, therefore it can be concluded that the stability loss occurs through the node snapping. At the instant of construction buckling works in the elastic area was also examined. The value of critical stress (limit of proportionality) and the corresponding of the limit of slenderness ratio was determined: $\lambda_{g r}=81.07$. Then this value was compared with estimated value of slenderness ratio: $\lambda=84.83>\lambda_{\mathrm{gr}}=81.07$.

Using the method of constant arc length [8], [9] and the method of the current stiffness parameter [2], the equilibrium path, and consequently, coordinates of the limit point: $q=10.02 \mathrm{~cm}, \mu=17.95$ were determined. On the basis of these coordinates, the limit function as the condition of the non-exceeding of the admissible vertical load multiplier of node 1 was formulated: $g_{1}(\mathbf{X})=1-\mu(\mathbf{X}) / 17.95$.

In the reliability analysis of the truss structure shown in Fig. 2, the following variables are used: $\mathrm{X}_{1}$ - load of node $1 \mathrm{P}=10 \mu, \mathrm{X}_{2}$ - axial stiffness EA, $\mathrm{X}_{3}$ - coordinate $\mathrm{Z}$ of node 1 . Random variables are not correlated. Description of the random variables is shown in Table 1. 
Table 1. Description of the random variables.

\begin{tabular}{|c|c|c|c|c|}
\hline Random variable & $\begin{array}{c}\text { Probability density } \\
\text { function }\end{array}$ & Mean value & Standard deviation & Coefficient of variation \\
\hline $\mathrm{X}_{1}$ & Gumbel & $10 \mathrm{kN}$ & $1 \mathrm{kN}$ & $10 \%$ \\
\hline $\mathrm{X}_{2}$ & Normal & $907334 \mathrm{kN}$ & $90733.4 \mathrm{kN}$ & $10 \%$ \\
\hline $\mathrm{X}_{3}$ & Normal & $1.486 \mathrm{~m}$ & $0.14 \mathrm{~m}$ & $9.43 \%$ \\
\hline
\end{tabular}

Changing the value of the current stiffness parameter CSP, while approaching to the limit point, is shown in Fig. 3a and equilibrium path is presented in Fig. 3b.

a)

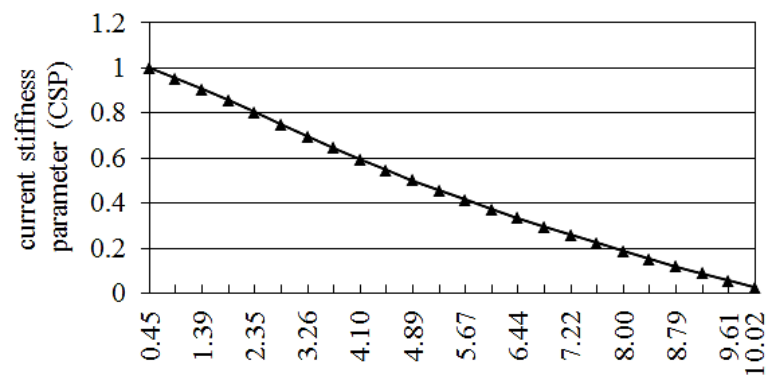

displacement (q) $[\mathrm{cm}]$

b)

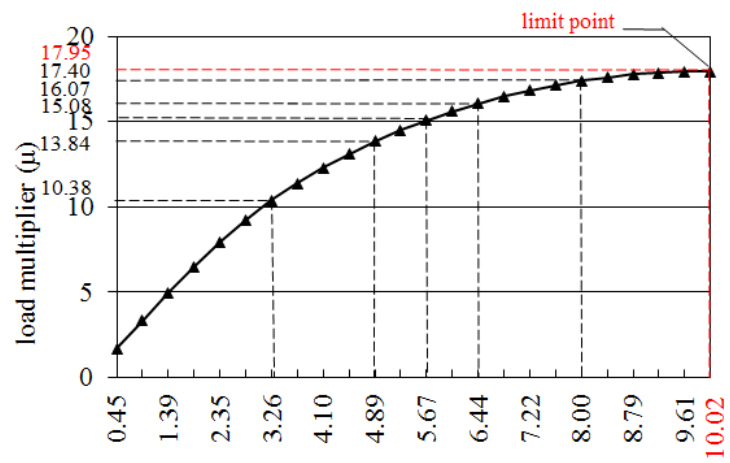

displacement (q) $[\mathrm{cm}]$

Fig. 3. a) Dependence of the current stiffness parameter (CSP) on the vertical displacement node 1 for nonlinear geometrical solution, b) Equilibrium path of the bar structure. 
Numerical results effects of changes on Hasofer-Lind reliability index value for different descriptions of the computational model are shown in Fig. 4. It may be noted that the introduction of successive random variables decreases the reliability index values.

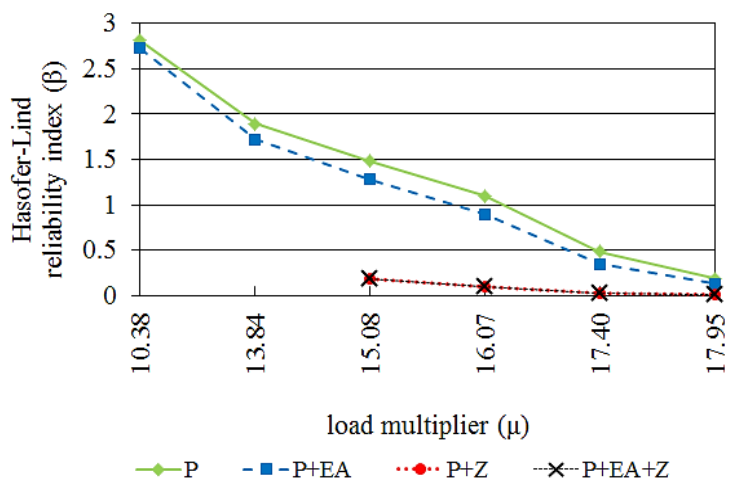

Fig. 4. Effect of the computational model description on the reliability index value.

The reliability index values were determined using the FORM method. A comparative analysis was performed, with the Monte Carlo method serving as a reference, to validate the computations. Exemplary results are shown in Fig. 5 in which the computational model was described by one random variable "P" (Fig. 5a.), and two random variables "P" and "EA" (Fig. 5b.). The timescale of computations, which is related to number of calls of the limit function, should also be taken into account (Table 2).

Table 2. Number of calls the limit function for various computational models.

\begin{tabular}{|c|c|c|c|c|c|c|c|c|}
\hline \multirow{2}{*}{\begin{tabular}{c} 
Load \\
multiplier \\
\cline { 2 - 9 } $\boldsymbol{\mu}$
\end{tabular}} & \multicolumn{2}{|c|}{ FORM method } & \multicolumn{2}{|c|}{$\begin{array}{c}\text { MONTE CARLO } \\
\text { method }\end{array}$} & \multicolumn{2}{|c|}{ FORM method } & \multicolumn{2}{|c|}{$\begin{array}{c}\text { MONTE CARLO } \\
\text { method }\end{array}$} \\
\cline { 2 - 9 } & $\begin{array}{c}\text { The } \\
\text { reliability } \\
\text { index } \boldsymbol{\beta}\end{array}$ & $\begin{array}{c}\text { Number } \\
\text { of the } \\
\text { limit } \\
\text { function } \\
\text { calls }\end{array}$ & $\begin{array}{c}\text { The } \\
\text { reliability } \\
\text { index } \boldsymbol{\beta}\end{array}$ & $\begin{array}{c}\text { Number } \\
\text { of the } \\
\text { limit } \\
\text { function } \\
\text { calls }\end{array}$ & $\begin{array}{c}\text { The } \\
\text { reliability } \\
\text { index } \boldsymbol{\beta}\end{array}$ & $\begin{array}{c}\text { Number } \\
\text { of the } \\
\text { limit } \\
\text { function } \\
\text { calls }\end{array}$ & $\begin{array}{c}\text { The } \\
\text { reliability } \\
\text { index } \boldsymbol{\beta}\end{array}$ & $\begin{array}{c}\text { Number } \\
\text { of the } \\
\text { limit } \\
\text { function } \\
\text { calls }\end{array}$ \\
\hline 10.38 & 2.81 & 24 & 2.76 & 10000 & 2.73 & 28 & 2.69 & 10000 \\
\hline 13.84 & 1.89 & 17 & 1.96 & 4000 & 1.72 & 21 & 1.77 & 3000 \\
\hline 15.08 & 1.48 & 12 & 1.57 & 2000 & 1.28 & 16 & 1.27 & 1000 \\
\hline 16.07 & 1.10 & 12 & 1.06 & 1000 & 0.89 & 16 & 0.79 & 500 \\
\hline 17.40 & 0.48 & 12 & 0.46 & 500 & 0.35 & 11 & 0.20 & 500 \\
\hline 17.95 & 0.19 & 8 & 0.18 & 500 & 0.13 & 11 & 0.03 & 500 \\
\hline
\end{tabular}


a)

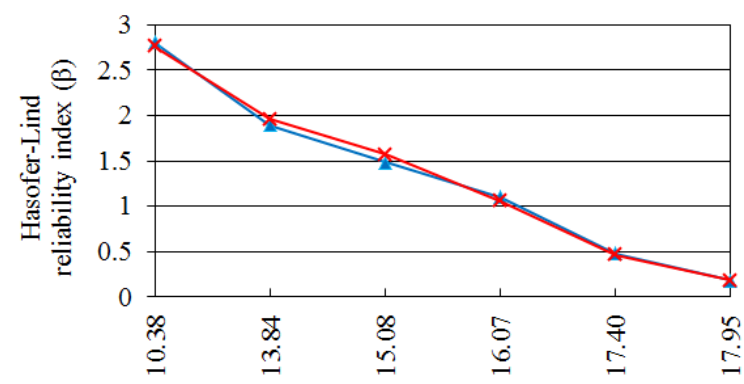

load multiplier $(\mu)$

$₫$ FORM method $\quad *$ MONTE CARLO method

b)

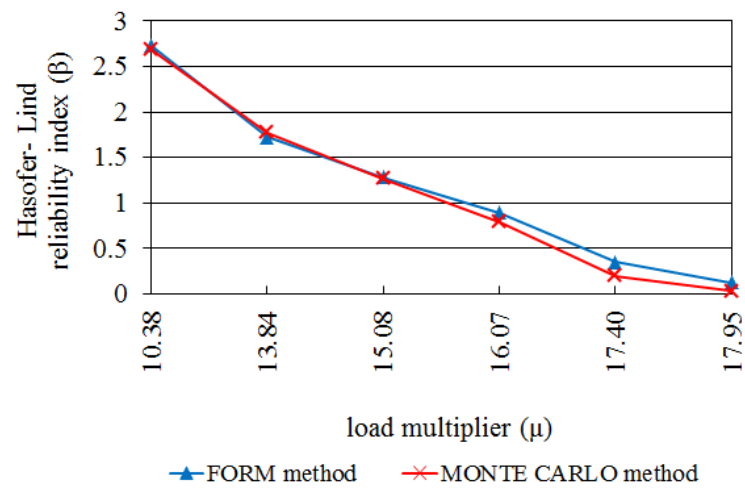

Fig. 5. The effect of reliability analysis method on the value of the reliability index for the computational model described by a) the random variable $\mathrm{P}, \mathrm{b}$ ) the random variables $\mathrm{P}$ and $\mathrm{EA}$.

\section{PROBABILISTIC METHODS IN DYNAMIC ANALYSIS OF STEEL FRAME}

The second part of present study deals with the problems of probabilistic methods of dynamic analysis performed for a steel industrial building located in Poland. Its basic supporting structure consisted of steel frames with rigid nodes in the ridge line, column-to-foundation connections and beam-to-column connections (Fig. 6). 

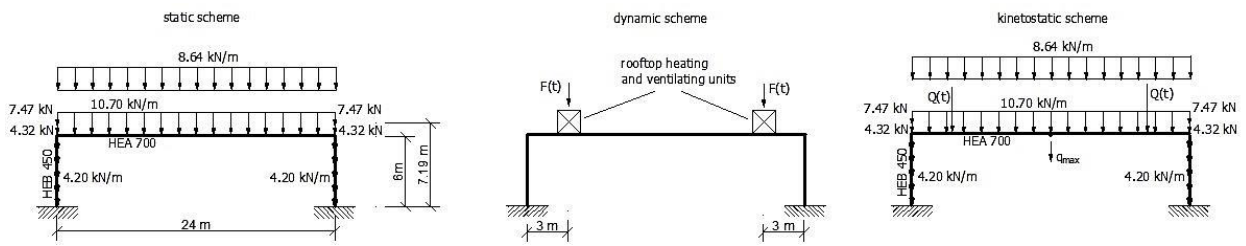

Fig. 6. Supporting structure of the steel industrial hall subjected to dynamic load.

All members were made of S235JR steel with the yield point $\mathrm{f}_{\mathrm{y}}=235 \mathrm{MPa}$ and modulus of elasticity E=210 GPa. Columns were designed of HEB 450 I-shaped beams, and girts of HEA 700 I-shaped beams. The initial analysis, performed with the Robot Structural Analysis Professional 2009, showed that the maximum girt deflection was obtained for the combination of permanent and snow loads (Fig. 6). The structure analysis was performed assuming the linear-elastic material model and small displacements.

The impact of the dynamic load was taken into account in the form of impact on the supporting structure of rooftop heating and ventilating units, placed on the roof of the structure, symmetrically at a distance of $3 \mathrm{~m}$ from the curtain wall. This load was assumed to cause forced vibration due to harmonic force. Using the principle of d'Alembert, static and dynamic scheme was replaced by kinetostatic model and analyzed by static methods. The effect of the impact of the rooftop heating and ventilating units was included in the analysis by defining the value of the exciting force $\mathrm{P}_{0}=10 \mathrm{kN}$ (weight of devices) and the frequency of the exciting force $\omega=16.67 \mathrm{1} / \mathrm{s}$. The effect of damping is not taken into account in this calculation. The limit functions imposed on the load bearing structure are displacement constraints related to the serviceability limit state. The initial analysis of the displacement state, performed with the Robot software, made it possible to locate the sites at which displacement extreme values occur. Then, with the MES3D program, using the Finite Element Method, the maximum vertical displacement of node in the middle of girt span was determined. Below, probabilistic quantities are specified:

$\mathrm{X}_{1}$ - permanent load from the covering self-weight from $1 \mathrm{~m}$ of the roof plane,

$\mathrm{X}_{2}$ - permanent load from the cladding self-weight from $1 \mathrm{~m}$ of the curtain wall,

$\mathrm{X}_{3}$ - permanent load from a fragment of the roof and wall at the eave reduced to a focused force acting on the structure column,

$\mathrm{X}_{4}$ - load from uniform snow load imposed on the roof plane,

$\mathrm{X}_{5}$ - variable load from a fragment of the roof and wall at the eave reduced to a focused force acting on the structure column, 
$\mathrm{X}_{6} \quad$ - elastic modulus for S235JR,

$\mathrm{X}_{7}$ - load of exciting force resulting from the weight of the rooftop heating and ventilating units,

$\mathrm{X}_{8}-$ member inertia moments of HEB450 columns,

$\mathrm{X}_{9}-$ member inertia moments of HEA700 girt,

$\mathrm{X}_{10}-$ member section area of HEB450 columns,

$\mathrm{X}_{11}$ - member section area of HEA700 girt.

Limit functions were defined as functions of random variables grouped in six different vectors.

The following cases of random variables vector were analysed:

Case $A: \mathbf{X}=\left\{X_{1}, X_{2}, X_{3}, X_{7}\right\}$,

Case $B: X=\left\{X_{1}, X_{2}, X_{3}, X_{4}, X_{5}, X_{7}\right\}$,

Case $C: X=\left\{X_{1}, X_{2}, X_{3}, X_{4}, X_{5}, X_{6}, X_{7}\right\}$,

Case D : $\mathbf{X}=\left\{\mathrm{X}_{7}, \mathrm{X}_{8}, \mathrm{X}_{9}, \mathrm{X}_{10}, \mathrm{X}_{11}\right\}$,

Case $E: X=\left\{X_{6}, X_{7}, X_{8}, X_{9}, X_{10}, X_{11}\right\}$,

Case $F: X=\left\{X_{1}, X_{2}, X_{3}, X_{4}, X_{5}, X_{6}, X_{7}, X_{8}, X_{9}, X_{10}, X_{11}\right\}$.

Table 3. Description of the random variables.

\begin{tabular}{|c|c|c|c|c|}
\hline Random variable & $\begin{array}{c}\text { Probability density } \\
\text { function }\end{array}$ & Mean value & Standard deviation & $\begin{array}{c}\text { Coefficient of } \\
\text { variation }\end{array}$ \\
\hline $\mathrm{X}_{1}$ & Normal & $10.70 \mathrm{kN} / \mathrm{m}$ & $1.07 \mathrm{kN} / \mathrm{m}$ & $10 \%$ \\
\hline $\mathrm{X}_{2}$ & Normal & $4.20 \mathrm{kN} / \mathrm{m}$ & $0.42 \mathrm{kN} / \mathrm{m}$ & $10 \%$ \\
\hline $\mathrm{X}_{3}$ & Normal & $7.47 \mathrm{kN}$ & $0.745 \mathrm{kN}$ & $10 \%$ \\
\hline $\mathrm{X}_{4}$ & Normal & $8.64 \mathrm{kN} / \mathrm{m}$ & $0.864 \mathrm{kN} / \mathrm{m}$ & $10 \%$ \\
\hline $\mathrm{X}_{5}$ & Normal & $4.32 \mathrm{kN}$ & $4.32 \mathrm{kN}$ & $10 \%$ \\
\hline $\mathrm{X}_{6}$ & Normal & $210 \cdot 10^{6} \mathrm{kN} / \mathrm{m}^{2}$ & $84 \cdot 10^{5} \mathrm{kN} / \mathrm{m}^{2}$ & $4 \%$ \\
\hline $\mathrm{X}_{7}$ & Normal & $10 \mathrm{kN}$ & $1 \mathrm{kN}$ & $10 \%$ \\
\hline $\mathrm{X}_{8}$ & Normal & $79890 \cdot 10^{-8} \mathrm{~m}^{4}$ & $39945 \cdot 10^{-9} \mathrm{~m}^{4}$ & $5 \%$ \\
\hline $\mathrm{X}_{9}$ & Normal & $215300 \cdot 10^{-8} \mathrm{~m}^{4}$ & $107650 \cdot 10^{-9} \mathrm{~m}^{4}$ & $5 \%$ \\
\hline $\mathrm{X}_{10}$ & Normal & $218 \cdot 10^{-4} \mathrm{~m}^{2}$ & $109 \cdot 10^{-5} \mathrm{~m}^{2}$ & $5 \%$ \\
\hline $\mathrm{X}_{11}$ & Normal & $260 \cdot 10^{-4} \mathrm{~m}^{2}$ & $130 \cdot 10^{-5} \mathrm{~m}^{2}$ & $5 \%$ \\
\hline
\end{tabular}

The frequency of the exciting force and lengths of columns and girt were assumed to be deterministic quantities. Limit functions as the condition of the non-exceeding of the admissible vertical displacement of node in the middle of the girt span was formulated: $g_{2}(\mathbf{X})=1-\left|q_{\max }(\mathbf{X})\right| / q_{\text {dop }}$ where $\mathrm{q}_{\mathrm{dop}}=\mathrm{L} / 250$ denotes permissible displacement in accordance with [4]. For the structure under consideration, value $\mathrm{q}_{\mathrm{dop}}=0.096 \mathrm{~m}$. 
The values of the Hasofer-Lind reliability index were determined with the FORM method, and for the sake of comparison, with simulation methods, i.e. Monte Carlo and Importance Sampling. The STAND software was used. The results are presented in Table 4. Relative error of the Hasofer-Lind reliability index was estimated assuming that the reference is the Monte Carlo method (Table 5).

Table 4. Comparative analysis of the reliability index computations.

\begin{tabular}{|c|c|c|c|c|c|c|}
\hline \multirow{2}{*}{ Methods of the reliability analysis } & \multicolumn{5}{|c|}{ Case } \\
\cline { 2 - 7 } & A & B & C & D & E & F \\
\hline FORM & 4.25 & 3.31 & 1.59 & 2.73 & 1.58 & 1.38 \\
\hline MONTE CARLO & 4.25 & 3.43 & 1.63 & 2.75 & 1.54 & 1.41 \\
\hline Importance Sampling & 4.27 & 3.33 & 1.54 & 2.69 & 1.60 & 1.27 \\
\hline
\end{tabular}

Table 5. The relative error of determining the reliability index as regards the Monte Carlo method.

\begin{tabular}{|c|c|c|c|c|c|c|}
\hline \multirow{2}{*}{ Methods of the reliability analysis } & \multicolumn{7}{|c|}{ The relative error [\%] } \\
\cline { 2 - 8 } & \multicolumn{5}{|c|}{ Case } & D \\
\cline { 2 - 7 } & A & B & C & D & E & F \\
\hline FORM & 0 & 3.5 & 2.5 & 0.7 & 2.6 & 2.2 \\
\hline Importance Sampling & 0.5 & 0.6 & 5.5 & 2.2 & 2.5 & 2.2 \\
\hline
\end{tabular}

The reliability analysis performed with the STAND software also provides information on the number of limit state function calls, and thus, on the time necessary to estimate the reliability index (Table 6). In addition, the graph that shows the sensitivity of the reliability index to random variables was plotted (Fig. 7). In the sensitivity analysis (Fig. 7) the variable with the higher absolute value has the greater impact on the reliability index value. Also the random variables which the absolute value is small in comparison with others variables can be treated as a deterministic values.

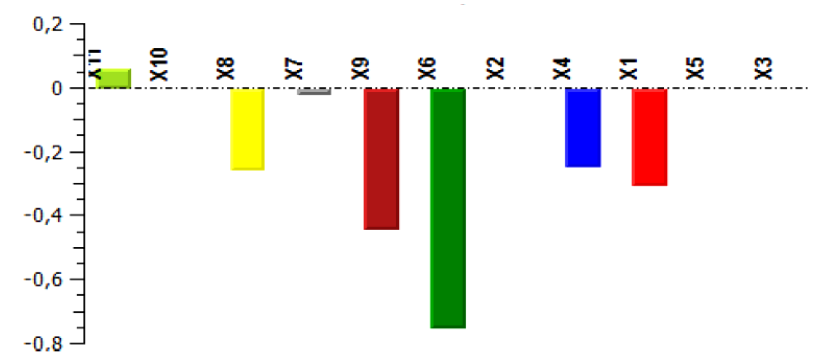

Fig. 7. Sensitivity of the reliability index $\beta$ to random variables. 
Table 6. The analysis of the effectiveness of the FORM method when compared with other methods.

\begin{tabular}{|c|c|c|c|c|c|c|}
\hline \multirow{2}{*}{ Case } & \multicolumn{5}{|c|}{ Methods of the reliability analysis } \\
\cline { 2 - 7 } & \multicolumn{2}{|c|}{ FORM } & \multicolumn{2}{c|}{ Monte Carlo } & \multicolumn{2}{c|}{ Importance Sampling } \\
\cline { 2 - 7 } & $\begin{array}{c}\text { Number of limit } \\
\text { state function calls }\end{array}$ & $\begin{array}{c}\text { Computation } \\
\text { time }\end{array}$ & $\begin{array}{c}\text { Number of limit } \\
\text { state function calls }\end{array}$ & $\begin{array}{c}\text { Computation } \\
\text { time }\end{array}$ & $\begin{array}{c}\text { Number of limit } \\
\text { state function calls }\end{array}$ & $\begin{array}{c}\text { Computation } \\
\text { time }\end{array}$ \\
\hline A & 51 & $11 \mathrm{~s}$ & 10000 & $22 \mathrm{~m} 5 \mathrm{~s}$ & 551 & $2 \mathrm{~m} 7 \mathrm{~s}$ \\
\hline B & 53 & $18 \mathrm{~s}$ & 10000 & $52 \mathrm{~m} 41 \mathrm{~s}$ & 553 & $2 \mathrm{~m} 59 \mathrm{~s}$ \\
\hline C & 36 & $12 \mathrm{~s}$ & 2000 & $10 \mathrm{~m} 32 \mathrm{~s}$ & 536 & $2 \mathrm{~m} 48 \mathrm{~s}$ \\
\hline D & 38 & $23 \mathrm{~s}$ & 10000 & $55 \mathrm{~m} 34 \mathrm{~s}$ & 538 & $2 \mathrm{~m} 56 \mathrm{~s}$ \\
\hline E & 62 & $1 \mathrm{~m} 4 \mathrm{~s}$ & 2000 & $7 \mathrm{~m} 40 \mathrm{~s}$ & 562 & $2 \mathrm{~m} 8 \mathrm{~s}$ \\
\hline F & 83 & $28 \mathrm{~s}$ & 1500 & $7 \mathrm{~m} 53 \mathrm{~s}$ & 583 & $3 \mathrm{~m} 4 \mathrm{~s}$ \\
\hline
\end{tabular}

\section{CONCLUSIONS}

Using the methods of reliability analysis, moving along the equilibrium path of structure, we can determine reliability index and hence the level of failure probability when we approach to the limit point. Our considerations conclude with Fig. 4. This figure show changes of reliability index values while following the non-linear geometric solution path, when load is the only random variable. The remaining parameters of the problem are treated as deterministic variables. The values of the reliability index obtained with such a computational model are clearly higher than these in other series, which provides a much more comprehensive description of the problem (random variables describe the following: load, bar axial stiffness, coordinate $\mathrm{Z}$ of node 1). Accounting for a larger number of random variables extends the computation time, yet such a manner of formulating the problem makes it possible to give a more accurate evaluation of a structure safety.

The STAND software makes it possible to check the correctness of solutions obtained with the FORM method by applying the Monte Carlo method. Graphs describing the effect of reliability analysis method on the value of the reliability index are presented in Fig. 6. On this basis we can say that the graphs for both methods almost overlap and the highest relative error is almost $8 \%$.

The second part of present study considers the problems of probabilistic methods in dynamic analysis. Accounting for a larger number of random variables considerably reduces the reliability index value (Table 4) but makes it possible to give a more accurate evaluation of a structure safety. The relative error in the reliability index was estimated for individual methods at the assumption that the Monte Carlo (where sample size is 10000) served as the reference method. In dynamic analysis the highest relative error is $3.5 \%$ for " $\mathrm{B}$ " cases of random variables vector.

Another important component of the study was to investigate the sensitivity of the reliability index to changes in probabilistic characteristics of the random variables under consideration. After 
analysing the results obtained for Example 2 it can be seen that the sensitivity of the reliability index is the highest for the random variable $\mathrm{X}_{6}$ which describes the elastic modulus for S235JR. It is the lowest for the random variable $\mathrm{X}_{2}$ (permanent load from the cladding self-weight from $1 \mathrm{~m}$ of the curtain wall), $X_{3}$ (permanent load from a fragment of the roof and wall at the eave reduced to a focused force acting on the structure column) and $\mathrm{X}_{5}$ (variable load from a fragment of the roof and wall at the eave reduced to a focused force acting on the structure column). Knowing this sensitivity is crucial for better understanding the structure performance. If the reliability index sensitivity due to the random variable $X_{i}$ is low when compared with other variables, it can be stated that the impact of this variable on failure probability is small, and in successive computations it can be treated as a deterministic parameter.

The analysis of the results demonstrates that the FORM method is good enough and much simpler to apply. The timescale of computations, which is related to number of calls of the limit function, should also be taken into account. As regards the results in Tables 2 and 6 indicates that the FORM method allows obtaining a quick response, which makes it possible to use the method in engineering practice as one of the modules of computational software that support structure design. So we assume that the FORM method is sufficiently precise and authoritative research method.

\section{REFERENCES}

1. T. Abdo, R. Rackwitz, "Reliability of uncertain structural systems", Proc. Finite Elements in Engineering Applications: 161-176, Stuttgart, 1990.

2. P.G. Bergan, T.H. Soreide, "Solution of large displacement and stability using the current stiffness parameter", Conference "Finite Elements in nonlinear Mechanics", 647-669, Geilo, 1977.

3. Eurocode 3: Design of steel structures - Part 1-1: General rules and rules for buildings.

4. J. Knabel, K. Kolanek, V. Nguyen Hoang, R. Stocki, P. Tauzowski, "Structural reliability analysis using object oriented environment STAND” In proc. of the $36^{\text {th }}$ Solid Mechanics Conference, 9-12 September 2008, Gdansk, Poland.

5. A. Nataf, "Determination des distribution don't les Marges Sont Donees", Comptes Rendus de l'Academic des Sciences, 225, 42-43, 1962.

6. R. Rackwitz, B. Fiessler, "Structural reliability under combined random load sequences", Computers \& Structures, 9(5): 489-494, 1978.

7. U. Radon "Numerical aspects of application of FORM in node snapping truss structures", Archives of Civil and Mechanical Engineering, 15(1): 262-271, 2015.

8. E. Riks, "An incremental approach to the solution of snapping and buckling problems", International Journal of Solids and Structure, 15(7): 29-551, 1979.

9. E. Riks, "The application of Newton's method to the problem of elastic stability", Journal of Applied Mechanics 39: 1060-1065, 1972.

10. R. Stocki, K. Kolanek, J. Knabel, P. Tauzowski, "FE based structural reliability analysis using STAND environment", Computer Assisted Mechanics and Engineering Sciences, 16: 35-58, 2009.

11. W. Szaniec, K. Zielińska, "Modal analysis of selected bar domes”, Structure and Environment, 5(4): 15-20, 2013. 


\section{LIST OF FIGURES AND TABLES:}

Fig. 1. Scheme of communication between STAND software and external FE programs.

Rys. 1. Schemat współdziałania programu STAND z zewnętrznymi modułami metody elementów skończonych.

Fig. 2. The mesh elements and geometry of truss structure.

Rys. 2. Elementy siatki i geometria konstrukcji kratownicy.

Fig. 3. a) Dependence of the current stiffness parameter (CSP) on the vertical displacement node 1 for nonlinear geometrical solution, b) Equilibrium path of bar structure.

Rys. 3. a) Zależność skalarnego parametru sztywności (SPS) od przemieszczenia pionowego węzła nr 1 dla rozwiązania geometrycznie nieliniowego, b) Ścieżka równowagi konstrukcji prętowej.

Fig. 4. Effect of the computational model description on the reliability index value.

Rys. 4. Wpływ opisu modelu obliczeniowego na wartość wskaźnika niezawodności.

Fig. 5. The effect of reliability analysis method on the value of the reliability index for the computational model described by: a) the random variable $\mathrm{P}, \mathrm{b}$ ) the random variables $\mathrm{P}$ and $\mathrm{EA}$.

Rys. 5. Wpływ metody analizy niezawodności na wartość wskaźnika niezawodności dla modelu obliczeniowego opisanego przez: a) zmienną losową P, b) zmienne losowe P i EA.

Fig. 6. Supporting structure of the steel industrial hall subjected to dynamic load.

Rys. 6. Konstrukcja nośna stalowej hali przemysłowej poddana obciążeniom dynamicznym.

Fig. 7. Sensitivity of the reliability index $\beta$ to random variables.

Rys. 7. Wrażliwość wskaźnika niezawodności $\beta$ na zmienne losowe.

Tab. 1. Description of the random variables.

Tab. 1. Opis zmiennych losowych.

Tab. 2. Number of calls the limit function for various computational models.

Tab. 2. Liczba wywołań funkcji granicznej dla różnych modeli obliczeniowych.

Tab. 3. Description of the random variables.

Tab. 3. Opis zmiennych losowych.

Tab. 4. Comparative analysis of the reliability index computations.

Tab. 4. Analiza porównawcza oszacowania wskaźnika niezawodności.

Tab. 5. The relative error of determining the reliability index as regards the Monte Carlo method.

Tab. 5. Błąd względny wyznaczenia wskaźnika niezawodności w odniesieniu do metody Monte Carlo.

Tab. 6. The analysis of the effectiveness of the FORM method when compared with other methods.

Tab. 6. Analiza efektywności metody FORM w porównaniu do innych metod. 


\section{OCENA ALGORYTMÓW OBLICZANIA WSKAŹNIKA NIEZAWODNOŚCI}

Slowa kluczowe: zmienne losowe, wskaźnik niezawodności, metoda FORM, wrażliwość wskaźnika niezawodności, stateczność, analiza dynamiczna, ścieżka równowagi, punkt projektowy.

\section{STRESZCZENIE:}

W pracy przedstawiono problem stateczności i dynamiki konstrukcji prętowych z wykorzystaniem podejścia probabilistycznego. Posłużono się niejawną funkcją graniczną zmiennych losowych. Zależność taka wymaga zastosowania procedury numerycznej np. metody elementów skończonych. W pracy przedstawiono połączenie programu niezawodnościowego STAND z zewnętrznymi modułami MES: KRATA i MES3D.

W pierwszej części pracy analizowano problem stateczności i niezawodności przestrzennej konstrukcji prętowej podatnej na zjawisko przeskoku węzła. Konstrukcję zaprojektowano z profili rurowych RO 180x8. Elementy wykonano ze stali S355NH o granicy plastyczności $\mathrm{f}_{\mathrm{y}}=355 \mathrm{MPa}$ i module sprężystości $\mathrm{E}=210 \mathrm{GPa}$. Warunki podparcia zdefiniowano $\mathrm{w}$ postaci podpór przegubowo-nieprzesuwnych w węzłach zewnętrznych oraz w formie podparcia słupami. Dokonano weryfikacji założenia, że moment przeskoku nigdy nie będzie poprzedzony wyboczeniem poszczególnych prętów struktury. W związku z powyższym sprawdzono warunek nośności ze względu na wyboczenie dla najbardziej wytężonego pręta w chwili przeskoku węzła. Sprawdzono również czy w chwili wyboczenia konstrukcja pracuje w zakresie sprężystym. W tym celu wyznaczono wartość naprężeń krytycznych (granica proporcjonalności) i odpowiadającą im smukłość graniczną.

Kolejny etap analizy polegał na zastosowaniu metody stałej długości łuku oraz metody skalarnego parametru sztywności do wyznaczenia ścieżki równowagi, a w konsekwencji, współrzędnych punktu granicznego:

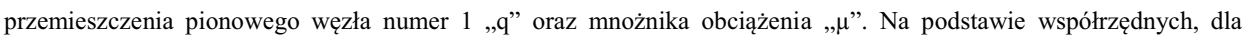
rozwiązania geometrycznie nieliniowego, sformułowano postać funkcji granicznej jako warunek nieprzekroczenia dopuszczalnego mnożnika obciążenia węzła numer 1 . Na tym etapie obliczeń posłużono się modułem metody elementów skończonych KRATA. W analizie niezawodności zdefiniowano następujące zmienne losowe: $\mathrm{X}_{1}-$ obciążenie siłą „P” węzła numer $1, \mathrm{X}_{2}$ - sztywność osiowa „EA” oraz $\mathrm{X}_{3}$ - współrzędna „Z” węzła numer 1. Zmienne losowe nie były skorelowane. Sporządzono wykresy prezentujące: zbliżanie się do punktu granicznego poprzez zmianę wartości skalarnego parametru sztywności, ścieżkę równowagi oraz wpływ zmian wartości wskaźnika niezawodności Hasofer-Linda dla różnych opisów modelu obliczeniowego. Decydującym czynnikiem wpływającym na wartość wskaźnika niezawodności jest wprowadzenie w opisie modelu obliczeniowego zmiennej losowej opisującej współrzędną „Z” węzła numer 1. Poprawność obliczeń wykonanych za pomocą metody FORM zweryfikowano poprzez porównanie z wartościami wskaźnika niezawodności obliczonego metodą Monte Carlo. Przykładowe zestawienie przedstawiono dla modeli obliczeniowych opisanych przez jedną zmienną „P” oraz przez dwie zmienne losowe: „P” i „EA”. Oceny efektywności metody FORM dokonano również poprzez porównanie liczby wywołań funkcji granicznej z metodą symulacyjną Monte Carlo.

Druga część pracy prezentuje problem zastosowania metod probabilistycznych w analizie dynamicznej stalowej hali przemysłowej. Analizę niezawodności przeprowadzono dla konstrukcji ortogonalnej ramy stalowej, która stanowi podstawowy element nośny hali. Wszystkie elementy wykonano z dwuteowników ze stali S235JR o granicy 
plastyczności fy=235 MPa i module sprężystości E=210 GPa. Słupy zaprojektowano z dwuteowników HEB 450 zaś na rygle przyjęto dwuteowniki HEA 700. Konstrukcja analizowana jest przy założeniu liniowo-sprężystego modelu materiału oraz małych przemieszczeń. Wpływ obciążeń dynamicznych został uwzględniony w postaci oddziaływania na konstrukcję nośną centrali wentylacyjno-grzewczej typu rooftop umieszczonej symetrycznie na dachu konstrukcji w odległości $3 \mathrm{~m}$ od ścian osłonowych. Przyjęto, że obciążenie to wywołuje drgania wymuszone siłą harmoniczną. Korzystając z zasady d'Alemberta schemat statyczny i dynamiczny zastąpiono schematem kinetostatycznym i analizowano metodami statyki budowli. W analizie uwzględniono wpływ oddziaływania centrali wentylacyjnogrzewczej definiując amplitudę siły wymuszającej oraz częstość kołową siły wymuszającej. Powyższe parametry centrali zostały przyjęte na podstawie analizy dokumentacji rzeczywistej instalacji wentylacyjnej hali o zbliżonych gabarytach do analizowanej konstrukcji oraz danych technicznych jednostek wentylacyjnych udostępnianych przez wiodących producentów. W obliczeniach nie uwzględniano wpływu tłumienia. Jako wielkości deterministyczne przyjęto: długości słupów i rygli, współrzędne węzłów i punktów podporowych oraz częstość kołową siły wymuszającej. Zdefiniowano również wielkości o charakterze probabilistycznym jako zmienne od $\mathrm{X}_{1}$ do $\mathrm{X}_{11}$, które możemy podzielić na dwie grupy. Pierwszą grupę stanowią zmienne z zakresu obciążeń: obciążenie stałe od ciężaru własnego pokrycia połaci dachowej oraz obciążenie stałe od ciężaru własnego okładziny ściany osłonowej. Drugą grupę stanowią charakterystyki materiałowe: moduł sprężystości, granica plastyczności, momenty bezwładności słupów i rygla oraz ich pola przekroju. Funkcją graniczną nałożoną na konstrukcję nośną są ograniczenia przemieszczeniowe związane ze stanem granicznym użytkowalności. Wstępna analiza stanu przemieszczeń i sił wewnętrznych wykonana za pomocą programu Robot pozwoliła zlokalizować miejsca występowania jego ekstremalnych wartości. Następnie stosując moduł MES3D, wykorzystujący Metodę Elementów Skończonych, wyznaczono maksymalną wartość przemieszczenia w węźle w połowie rozpiętości rygla. Przyjęto, że funkcje graniczne w analizie niezawodności zostaną zdefiniowane jako funkcje sześciu różnych wektorów zmiennych losowych (przypadki A-F). Wyznaczono wartość wskaźnika niezawodności Hasofera-Linda za pomocą metody FORM oraz, w celu weryfikacji poprawności obliczeń, za pomocą metod symulacyjnych tj.: Monte Carlo i Importance Sampling. W analizie wykorzystano połączenie programu niezawodnościowego STAND z modułem metody elementów skończonych MES3D. W związku z tym, że metoda symulacyjna Monte Carlo uznawana jest za najdokładniejszą i najbardziej wiarygodną w ocenie niezawodności konstrukcji, oszacowano błąd względny wyznaczenia wskaźnika niezawodności przyjmując jako referencyjną metodę Monte Carlo. Analiza niezawodności za pomocą programu STAND umożliwiała ocenę efektywności metody FORM poprzez porównanie informacji o liczbie wywołań funkcji granicznej, a co z tym związane o czasie obliczeń oszacowania wskaźnika niezawodności. Dodatkową informacją uzyskaną z programu niezawodnościowego jest wykres przedstawiający wrażliwość wskaźnika niezawodności na poszczególne zmienne losowe.

W analizie stateczności i dynamiki możemy zauważyć, że większa liczba zmiennych losowych wydłuża czas obliczeń, ale jednocześnie taki sposób formułowania problemu pozwala na dokładniejszą i bardziej wiarygodną ocenę bezpieczeństwa konstrukcji. Niewielki błąd względny wyznaczenia wskaźnika niezawodności oszacowany dla poszczególnych metod przy założeniu, że metodą odniesienia jest metoda Monte Carlo, prowadzi do wniosku, że metoda FORM jest wystarczająco dokładna i jednocześnie prostsza w zastosowaniu. 